\title{
Longitudinal Associations Among Marital Conflict, Co-Parenting, and Children's Internalizing and Externalizing Problem Behaviors
}

\author{
Youngsook Han \\ Research Associate, Center for Children and Families Across Cultures, University of Missouri, Columbia, USA \\ 부부갈등, 부모공동양육, 아동의 내재적·외현적 문제행동 간의 종단적 관계 \\ 한영숙 \\ 미주리대학교 다문화 아동·가족센터 연구원
}

Objectives: The present study examined the longitudinal associations between mothers' and fathers' perceptions of marital conflict and children's internalizing and externalizing problem behaviors. In particular, the study explored the mediating roles of mothers' and fathers' positive co-parenting and co-parenting conflict in these links.

Methods: This study analyzed the data of 2,150 children ( $M$ age $=4$ years at T1) and their parents from the panel study on Korean children. A path analysis was conducted to investigate the links among the study variables.

Results: Mothers' and fathers' perceptions of marital conflict were directly associated with children's subsequent externalizing problem behavior. Mothers' and fathers' perceptions of marital conflict were also directly related to their own and partners' positive co-parenting and co-parenting conflict at a later time point. Mothers' positive co-parenting and co-parenting conflict predicted children's subsequent internalizing and externalizing problem behaviors. Moreover, mothers' positive co-parenting and coparenting conflict were mediators in the relations between mothers' and fathers' perceptions of marital conflict and children's internalizing and externalizing problem behaviors.

Conclusion: The present results enhance our understanding of the underlying mechanisms that explain the longitudinal links between marital conflict and children's internalizing and externalizing problem behaviors.

Keywords: marital conflict, co-parenting, internalizing problem behavior, externalizing problem behavior, children

\section{Introduction}

부부갈등은 아동의 내재적·외현적 문제행동과 같은 다양 한 심리사회적 적응을 예측하는 중요한 요인이다(Cummings \& Davies, 2010). 선행연구들에서 부부 간의 갈등해결방식이 비난이나 무시와 같은 부정적·비기능적인 형태로 표출될수

Corresponding Author: Youngsook Han, Research Associate, Center for Children and Families Across Cultures, University of Missouri, 314 Gentry Hall, Columbia, USA

E-mail:yhm88@missouri.edu
록 아동은 공격적이고 비사회적이며 내재적인 문제행동을 더 많이 보이는 것으로 나타났다(Buehler et al., 1997; Katz \& Gottman, 1993). 이에 대하여 연구자들은 부부갈등이 어떠한 과정을 통하여 아동의 심리사회적 적응에 영향을 미치는지에 대해 설명할 수 있는 메커니즘에 관심을 가져왔다. 그동안 선 행연구들에서는 이를 설명하는 주요한 경로로써 부모의 양육

(C)The Korean Association of Child Studies

This is an Open Access article distributed under the terms of the Creative Commons Attribution Non-Commercial License (http:// creativecommons.org/licenses/by-nc/4.0) which permits unrestricted noncommercial use, distribution, and reproduction in any medium, provided the original work is properly cited. 
행동에 주목하였고, 이와 관련된 연구들이 다수 진행되어 오 고 있다(Buehler \& Gerard, 2004; Lindsey, Caldera, \& Tankersley, 2009). 그러나 양육행동 외에 다른 어떠한 요인이 부부갈등과 아동의 사회정서적 발달을 설명하는지에 대한 관심과 연구가 부족한 실정이다. Katz와 Low (2004)는 부모의 공동양육이 부 부갈등과 아동의 문제행동 간의 관계를 설명할 수 있다고 보 았다. 부모공동양육이란 두 성인이 자녀의 양육에 있어 부모 로서 공유하는 책임감과 활동으로, 상대방의 양육행동과 노력 에 대해 지지하는 긍정적인 공동양육 형태와 상대방을 비난하 거나 사기를 떨어뜨리는 형태의 부정적인 공동양육으로 특징 지어질 수 있다(Margolin, Gordis, \& John, 2001). 부부갈등 또 는 부모의 양육행동은 양자관계(dyadic relationships)에 바탕을 두고 있는 반면에 부모공동양육은 어머니, 아버지, 아동 세 사 람 간의 관계(triadic relationships)를 배경으로 한다는 점에서 차이가 있다(Stroud, Durbin, Wilson, \& Mendelsohn, 2011). 선 행연구들에 따르면, 부정적인 형태의 부부갈등이 많이 표출될 수록 협력적인 공동양육행동은 더 적게 나타나고, 공동양육 갈등과 같은 부정적 유형의 공동양육 행동은 더 많이 나타났 다(Jang \& Choi, 2015; Katz \& Low, 2004; Margolin et al., 2001). 또한 부모의 공동양육 행동이 아동의 내재적-외현적 문제행 동을 예측하는 것으로 나타났다(Katz \& Low, 2004; Murphy, Boyd-Soisson, Jacobvitz, \& Hazen, 2017). 따라서 부모의 공동양 육이 부부갈등과 아동의 문제행동 간의 관계를 설명하는 매개 역할을 하는지에 대해 알아볼 필요가 있다. 또한 대부분의 선 행연구들에서는 어머니의 응답을 기반으로 한 결과이기 때문 에 구체적으로 어머니와 아버지가 지각하는 부부갈등이 자신 과 배우자의 공동양육행동에 어떠한 영향을 미치는지, 그리고 어머니와 아버지의 공동양육행동이 아동의 내재적-외현적 문 제행동에 각각 어떠한 영향을 미치는지에 대하여 간과한 측면 이 있다. 아울러 종단 자료를 바탕으로 부부갈등, 부모공동양 육, 아동의 내재적·외현적 문제행동 간의 지속적인 관계를 설 명하는 연구가 부족하였다. 따라서 본 연구는 어머니와 아버 지가 지각하는 부부갈등, 어머니와 아버지의 공동양육행동, 아동의 내재적·외현적 문제행동 간의 직접적·종단적 관계를 살펴보고, 부부갈등과 아동의 문제행동 간의 관계에서 어머 니와 아버지의 공동양육행동이 매개 역할을 하는지 알아보고 자 하였다. 아래에서는 부부갈등, 부모공동양육, 아동의 내재 적·외현적 문제행동에 대한 선행연구들을 구체적으로 살펴보 고자 한다.

선행연구들에서 부부갈등은 아동의 내재적·외현적 문제 행동을 직접적으로 예측하는 것으로 나타났다(Buehler et al.,
1997; Camisasca, Miragoli, \& Blasio, 2016; Kaczynski, Lindahl, Malik, \& Laurenceau, 2006; Katz \& Gottman, 1993; Xuan et al., 2018). 부부갈등은 부부 간의 다양한 문제에 대하여 의견이나 이익이 상충될 때 이를 해결하는 행동, 정서, 전략의 차이에 의 해 달라지는데 상대방에 대한 비난이나 욕설과 같은 부정적 인 형태의 갈등으로 표출될 수도 있고, 상대방을 인정하고 합 리적인 방식으로 설득하는 협력적인 갈등 형태로도 표출될 수 있다(Buehler et al., 1997). 연구자들은 68개의 연구들을 메 타분석 한 결과, 부부갈등이 5 세부터 18 세까지의 아동의 내재 적·외현적 문제행동과 직접적 관계가 있는 것으로 나타났다 (Buehler et al., 1997). 또 다른 연구에서도 어머니가 지각한 부 정적인 형태의 부부갈등이 높을수록 33 개월부터 82 개월까지 의 아동의 내재적·외현적 문제행동이 더 높은 수준으로 나타 나는 경향이 있었다(Xuan et al., 2018). 한편, 부부갈등과 아동 의 부적응 간의 횡단 관계를 연구한 대부분의 선행연구들과 다르게, Brock과 Kochanska (2016)는 아동이 만 2세일 때 측정 된 부부갈등이 아동의 나이가 만 10 세일 때 이들의 내재적 문 제행동을 예측하는지에 대한 종단연구를 실시하였다. 그 결 과, 회피, 상호작용 거부, 언어적 공격성, 부부갈등에 자녀를 포함시키기와 같은 특징으로 나타나는 부정적인 형태의 부부 갈등은 이후 아동의 내재적 문제행동과 직접적인 관계는 나타 나지 않았지만, 부부갈등이 아동의 정서적 안정성을 저하시킴 으로써 아동의 내재적 문제행동에 간접적인 영향을 주는 것으 로 나타났다(Brock \& Kochanska, 2016). 위 선행연구들을 종합 해보면, 부부갈등과 아동의 내재적·외현적 문제행동에 대한 직접적·횡단적 관계는 비교적 분명하게 밝혀졌으나 부부갈등 이 아동의 부적응에 미치는 지속적인 영향력에 대해서는 보다 많은 연구를 통해 연구변인들에 대한 이해를 높일 필요가 있 다.

또한 선행연구들에서 부부갈등은 부모의 공동양육행동 을 예측하는 요인으로 주목받고 있다(Jang \& Choi, 2015; Katz \& Low, 2004; Margolin et al., 2001). 구체적으로 Jang과 Choi (2015)의 연구에서는, 자녀가 지각하는 부부갈등의 빈도와 강 도가 높고 갈등의 해결이 쉽지 않을수록 부모의 지지적인 공 동양육행동은 낮게 나타나고, 비난적인 공동양육행동은 높게 나타나는 것으로 나타났다. 그러나 이 연구는 부부갈등과 공 동양육의 주체인 아버지가 포함되지 않아 결과를 해석하는 데 있어 한계가 있다(Jang \& Choi, 2015). 반면에, Margolin 등 (2001)의 연구에서는, 어머니와 아버지를 모두 연구에 포함시 켜 이들의 부부갈등과 공동양육행동 간의 관계를 살펴보았 다. 그 결과, 훈련된 관찰자가 평정한 어머니의 적대적·방어적 
인 부부관계행동이 높을수록 어머니 자신과 아버지의 긍정적 인 공동양육행동(협동성)은 더 낮았고, 부정적인 공동양육행 동(갈등, 부부갈등에 자녀를 포함시키기)은 더 높게 나타났다 (Margolin et al., 2001). 또한 아버지의 적대적·방어적인 부부관 계행동이 높을수록 아버지 자신과 어머니의 부정적인 공동양 육행동(부부갈등에 자녀를 포함시키기)은 더 높게 나타났으 며, 어머니의 긍정적 공동양육행동은 더 낮게 나타나는 경향 이 있었다(Margolin et al., 2001). 흥미롭게도 어머니의 부부관 계에서의 부정적인 행동이 전반적으로 어머니 자신과 배우자 인 아버지의 공동양육행동에 모두 영향을 준 반면, 아버지의 부정적인 부부관계 행동은 배우자인 어머니의 다양한 공동양 육행동을 더 예측하는 것으로 나타났다는 점이다. 따라서 이 러한 결과는 가족체계를 연구함에 있어 어머니와 아버지를 모 두 포함시켜 비교하는 것이 중요함을 시사하며, 가족구성원이 서로 영향을 주고받는 가족상호작용의 역동성을 보여주는 결 과라고 할 수 있다.

아울러 선행연구들에서 부모의 공동양육행동은 아동의 내 재적-외현적 문제행동을 예측하는 주요 요인으로 나타났다 (Katz \& Low, 2004; Murphy et al., 2017; Murphy, Jacobvitz, \& Hazen, 2016; Schoppe, Mangelsdorf, \& Frosch, 2001; Teubert \& Pinquart, 2010; Zemp, Johnson, \& Bodenmann, 2018). Teubert 와 Pinquart (2010)는 부모의 공동양육행동과 아동의 발달에 대한 59개의 선행연구들을 메타 분석하였고, 그 결과 부부가 함께 아이를 양육함에 있어 협조적일수록 자녀의 내재적·외 현적 문제행동은 낮게 나타난 반면, 갈등적인 공동양육 행동 을 보일수록 자녀는 내재적·외현적 문제행동을 더 많이 보이 는 것으로 나타났다. 또 다른 연구에서는 아동이 24 개월일 때 관찰자에 의해 측정된 부모의 경쟁적인 공동양육(자녀를 자 신의 편으로 만들기 위해 상대 배우자의 양육행동을 비난하는 행동)이 아동이 7세가 되었을 때 교사에 의해 측정된 아동의 외현적 문제행동을 예측하는지 살펴본 결과, 부모가 경쟁적인 공동양육행동을 많이 보일수록 아동은 외현적 문제행동을 더 많이 보이는 것으로 나타났다(Murphy et al., 2017). 위 선행연 구 결과들에서도 알 수 있듯이 갈등이나 비난과 같은 부정적 인 공동양육행동은 아동의 내재적·외현적 문제행동과 정적인 관계가 있으며, 지지와 협동과 같은 긍정적인 공동양육행동 은 아동의 내재적·외현적 문제행동과 부적인 관계가 있다는 것을 알 수 있다. 그러나 어머니와 아버지의 긍정적-부정적 공 동양육행동이 각각 아동의 내재적·외현적 문제행동을 어떻게 예측하는지에 대한 연구가 거의 없어, 어머니와 아버지의 세 부적인 공동양육행동과 아동의 심리사회적 적응 간의 종단적
관계를 밝히는 연구가 필요하다.

위 선행연구들에서 살펴본 바와 같이 부부갈등은 이후 부 모의 긍정적·부정적 공동양육행동을 예측하고(Christopher, Umemura, Mann, Jacobvitz, \& Hazen, 2015; Hardesty, Crossman, Khaw, \& Raffaelli, 2016), 부모의 긍정적·부정적 공동양육행동 은 아동의 내재적·외현적 문제행동을 예측한다고 볼 수 있다 (Camisasca, Miragoli, Blasio, \& Feinberg, 2019; Parkes, Green, \& Mitchell, 2019). 구체적으로는 부모가 지지적인 공동양육행동 을 보일수록 학령기 자녀의 공격성은 낮아지는 것으로 나타났 고(Jang \& Choi, 2015), 적대적인 공동양육행동을 더 많이 보 일수록 아동은 불안과 우울한 감정을 더 많이 느끼는 것으로 나타났다(Katz \& Low, 2004). 따라서 부부갈등이 부모공동양 육을 통하여 아동의 내재적-외현적 문제행동을 간접적으로 예측할 수 있다고 추측해 볼 수 있다. 그러나 부모의 공동양육 행동이 부부갈등과 아동의 내재적·외현적 문제행동 간의 관 계를 매개하는지에 대해 살펴본 연구가 거의 없어 이에 대한 이해가 부족하다(Stroud, Meyers, Wilson, \& Durbin, 2015). 또 한 부부갈등, 부모공동양육, 아동의 내재적·외현적 문제행동 간의 관계를 연구함에 있어 어머니와 아버지를 모두 분석한 연구들이 상대적으로 적고, 어머니와 아버지가 연구에 참여 했더라도 이들의 통합적인 공동양육행동을 평가하여 어머니 와 아버지가 지각한 부부갈등이 각각 자신과 배우자의 세부적 인 공동양육행동에 어떻게 영향을 미치는지에 대해 알기 어려 웠다. 아울러 부부갈등이 부모의 공동양육을 통하여 또는 직 접적으로 아동의 내재적·외현적 문제행동에 영향을 주는지에 대하여 종단설계를 바탕으로 알아볼 필요가 있다.

또한 아동 중기의 내재적.외현적 문제행동은 이후 청소년 기와 성인기의 다양한 영역의 발달과 적응을 예측하는 중요 한 요인이므로(Moilanen, Shaw, \& Maxwell, 2010; Odgers et al., 2008), 이 시기 아동의 문제행동을 감소시키고 긍정적인 발 달을 도모하는 방안을 모색하는 것은 매우 중요하다. Parkes, Green와 Mitchell (2019)은 영유아기의 부부관계 및 부모공동 양육과 같은 가족 기능들이 이후 아동기 자녀의 문제행동에 미치는 지속적인 영향력에 대하여 연구할 필요가 있음을 주장 하였다(Parkes et al., 2019). 특히 유아기는 많은 시간을 부모와 함께 보내고 부모와의 상호작용을 통해 영향을 받는 시기이 며(Han, 2019), 유아기 자녀를 둔 부모의 부부관계와 공동양 육 간의 관계가 영아기때보다 서로 더 밀접한 관련이 있는 것 으로 나타나(Schoppe-Sullivan, Mangelsdorf, Frosch, \& McHale, 2004), 유아기의 부부관계 및 부모공동양육이 이후 아동의 심 리사회적 발달을 어떠한 방식으로 얼마만큼 예측하는지 알아 
Table 1

Participants'Sociodemographic Characteristics

\begin{tabular}{|c|c|c|c|}
\hline & & Mother & Father \\
\hline & & \multicolumn{2}{|c|}{$n(\%)$} \\
\hline \multirow[t]{6}{*}{ Education levels } & No schooling & $1(.1)$ & $0(.0)$ \\
\hline & Middle school & $8(.5)$ & $10($. .6) \\
\hline & High school & $493(29.1)$ & $446(26.5)$ \\
\hline & College & $455(26.9)$ & $326(19.3)$ \\
\hline & University & $647(38.2)$ & $727(43.1)$ \\
\hline & Graduate school & $89(5.3)$ & $176(10.4)$ \\
\hline \multirow[t]{3}{*}{ Employment/studies status } & Employment/studies & $723(43.0)$ & $1531(94.7)$ \\
\hline & No employment/studies & $960(57.0)$ & $85(5.3)$ \\
\hline & & \multicolumn{2}{|c|}{$M(S D)$} \\
\hline Age & & $34.79(3.70)$ & $37.26(3.97)$ \\
\hline Earned income & & \multicolumn{2}{|c|}{$4,437,800(366.5)$ won } \\
\hline Assets income & & \multicolumn{2}{|c|}{$254,000(26.9)$ won } \\
\hline Publictransfer income & & \multicolumn{2}{|c|}{$51,000(17.9)$ won } \\
\hline Privatetransfer income & & \multicolumn{2}{|c|}{80,000 (136.9) won } \\
\hline Marriage duration & & \multicolumn{2}{|c|}{95.30 (39.17) months } \\
\hline
\end{tabular}

Note. $N=2,150$.

볼 필요가 있다.

아울러 부모의 사회경제적 수준 및 아동의 성별과 같은 연 구대상의 사회인구학적 변인들을 고려할 필요가 있다. 선행 연구들에 따르면, 부모의 사회경제적 수준이 낮을수록 아동 의 내재적·외현적 문제행동이 높아지는 것으로 나타났다(Bøe et al., 2014; Reising et al., 2013). 또한 연구자들은 남아가 여아 에 비해 외현적 문제행동을 더 많이 보이는 경향이 있고, 여아 는 남아에 비해 내재적 문제행동을 더 많이 나타내는 경향이 있음을 보고하고 있다(Leadbeater, Kuperminc, Blatt, \& Hertzog, 1999). 따라서 연구대상의 사회인구학적 변인들을 통제하여 주요 연구변인들 간의 관계를 보다 분명히 살펴볼 필요가 있 다.

종합해보면, 선행연구들의 제한점을 극복하고 연구변인들 에 대한 이해를 돕기 위하여 본 연구는 어머니와 아버지가 지 각하는 부부갈등, 어머니와 아버지의 긍정적 공동양육행동 과 공동양육 갈등, 아동의 내재적-외현적 문제행동 간의 직접 적·종단적 관계를 살펴보고자 하였다. 또한 어머니와 아버지 의 긍정적 공동양육행동과 공동양육 갈등이 어머니와 아버지 가 지각하는 부부갈등과 아동의 내재적-외현적 문제행동 간 의 관계를 매개하는지에 대하여 알아보고자 하였다. 연구문제 는 다음과 같다.

\section{연구문제 1}

어머니와 아버지가 지각하는 부부갈등, 어머니와 아버지의 긍정적 공동양육행동과 공동양육 갈등, 아동의 내재적·외현 적 문제행동 간의 직접적·종단적 관계가 있는가?

\section{연구문제 2}

어머니와 아버지가 지각하는 부부갈등과 아동의 내재적·외 현적 문제행동 간의 관계에서 어머니와 아버지의 공동양육행 동이 매개하는가?

\section{Methods}

\section{연구대상}

본 연구의 대상은 육아정책연구소의 한국아동패널 $5,7,8$ 차 년도에 참여한 2,150 명의 아동들과 부모들이다. 한국아동패 널 6차년도에는 부부갈등 변인이 포함되지 않아 5차년도 자 료를 사용하였고, 부모공동양육 변인은 7차년도부터 수집되 어 7차년도 자료가 본 연구에서 분석되었다. 한국아동패널 5 (Time 1), 7 (Time 2), 8차년도(Time 3)에 참여한 아동의 나이는 각각 만 4, 6, 7세이며, 남녀 비율이 각각 $51 \%, 49 \%$ 이다. 패널 
자료는 층화다단계 표본추출법을 통하여 수집되었는데, 전국 지역에서 30 개의 신생아 출산 의료기관을 추출한 후 어머니 들의 동의를 받은 2,562 가구를 예비표본으로 추출하였으며, 실제 패널연구에 참여한 2,150 가구를 표본으로 확정하였다 (Shin, Ahn, Lee, Song, \& Kim, 2008). Time 1대비 Time 2의 표 본유지율과 Time 2 대비 Time 3의 표본유지율은 각각 $94.2 \%$, $98.6 \%$ 으로 높은 수준이었다. 본 연구에 참여한 부모들의 사회 인구학적 정보(나이, 교육수준, 월 평균 근로소득, 자산소득, 공적이전소득, 사적이전소득, 취업/학업상태, 결혼지속기간) 는 Table 1에 제시한 바와 같다.

\section{연구도구}

\section{부부갈등}

어머니와 아버지는 Markman, Stanley와 Blumberg (1994, 2001) 의 도구를 한국아동패널 연구진들이 수정한 도구를 사용하여 자신들의 부부갈등에 대하여 응답하였다. 원 도구는 그렇다 또는 아니다로 응답하도록 구성되었지만 한국아동패널 연구 진이 전혀 그렇지 않다(1점)부터 매우 그렇다(5점)의 범위로 평정할 수 있도록 구성된 5점 리커트 척도로 수정하였다. 총 8 문항으로 구성되어 있으며, 척도의 점수가 높을수록 어머니와 아버지가 인지하는 부부갈등 수준이 높음을 의미한다. 문항 의 예로는 "사소한 말다툼이 큰 싸움으로 변해 서로 욕설하고 비난하며, 과거의 잘못을 다시 들추면서 싸운다.”, "남편(아내) 은 내 생각이나 기분 혹은 내가 원하는 것을 비난하고 별로 중 요하게 생각하지 않는다.", "남편(아내)은 나를 존중하지 않는 것 같다." 등이 있다. 본 연구에서 산출한 부부갈등 척도 8 문항 (Time 1)에 대한 내적합치도 계수 Cronbach's $\alpha$ 는 .92(어머니 응답), .91(아버지 응답)이었다.

\section{부모공동양육}

어머니와 아버지와 긍정적·갈등적 공동양육행동을 측정하 기 위하여 McHale (1997)의 가족통합(family integrity)과 갈등 (conflict) 하위척도가 사용되었다. McHale (1997)의 공동양 육 척도는 가족통합, 갈등, 비난, 훈육의 4 가지 하위척도들로 구성된 도구이지만 비난의 내적합치도 계수가 .42(어머니 응 답), .34(아버지 응답)로 나타났고, 훈육의 내적합치도 계수가 .15(어머니 응답), .14(아버지 응답)로 매우 낮아 비난과 훈육 하위척도는 본 연구에 포함되지 않았다. 공동양육 도구는 어
머니와 아버지가 공동양육 상황에서 각각 자신의 행동을 보 고하는 지필식 질문지이다 가족통합 척도는 공동양육 상황 에서 배우자 또는 자녀에게 협동적이고 지지적인 모습을 보 이는 긍정적인 공동양육을 의미하며, 총 7문항으로 구성되어 있다. 갈등 척도는 공동양육 상황에서 배우자 또는 자녀 앞에 서 분쟁 및 갈등을 표출하는 공동양육 갈등을 의미하고, 총 2 문항으로 구성되어있다. 또한 전혀 그렇지 않다(1점)부터 매 우 그렇다(7점)의 범위로 평정하도록 구성된 7점 리커트 척도 이다. 가족통합 척도(긍정적인 공동양육)의 예로는 다음과 같 다. "나는 나와 배우자, 아이가 함께 있을 때 아이에게 배우자 에 대한 칭찬이나 긍정적인 말을 한다.", "나는 배우자 없이 아 이가 함께 있을 때 아이가 배우자에 대해 긍정적인 이미지를 가질 수 있게 말을 한다.” 갈등 척도(갈등적인 공동양육)의 예 로는 다음과 같다. "나는 나와 배우자, 아이가 함께 있는 상황 에서 배우자와 이야기를 할 때 약간 긴장된 분위기가 조성되 거나 빈정거리며 말한다.", “나는 나와 배우자, 아이가 함께 있 을 때 배우자와 언쟁(말싸움)을 한다.” 본 연구에서는 선행연 구들과 마찬가지로 어머니와 아버지의 공동양육행동을 구별 하여 분석하였다(Margolin et al., 2001). 선행연구들에서 어머 니와 아버지의 공동양육행동 간의 상관이 낮게 보고되었는데 (Margolin et al., 2001), 본 연구에서도 어머니와 아버지의 긍 정적인 공동양육행동 간의 상관계수와 갈등적인 공동양육행 동 간의 상관계수가 각각 $.41, .47$ 로 .7보다 낮아 둘의 문항평 균을 합쳐서 분석하는 것보다 어머니와 아버지 각각 따로 분 석하는 것이 더 의미가 있다고 볼 수 있다. 본 연구에서 산출 한 긍정적인 공동양육 7문항(Time 2)에 대한 내적합치도 계수 Cronbach's $\alpha$ 는 어머니와 아버지 응답이 각각 $.86, .87$ 이었다. 본 연구에서 산출한 갈등적인 공동양육 2 문항(Time 2)에 대한 내적합치도 계수 Cronbach's $\alpha$ 는 어머니와 아버지 응답이 모 두 .77이었다.

\section{내재적. 외현적 문제행동}

어머니는 $\mathrm{Oh}$ 와 $\mathrm{Kim}$ (2010)의 아동·청소년 행동평가척도 (Child Behavior Checklist 6-18 [CBCL 6-18])를 사용하여 학령 기 아동의 내재적·외현적 문제행동을 평정하였다. 내재적 문 제행동은 불안/우울, 위축/우울, 신체증상 하위척도들을 통 해 평가하고, 총 32 문항으로 구성되어 있다. 외현적 문제행동 은 규칙위반과 공격행동 하위척도들을 통해 평가하고, 총 35 문항으로 구성되어 있다. 또한, 이 척도는 전혀 해당되지 않는 다(0점)부터 자주 그런 일이 있거나 많이 그렇다(2점)의 범위 


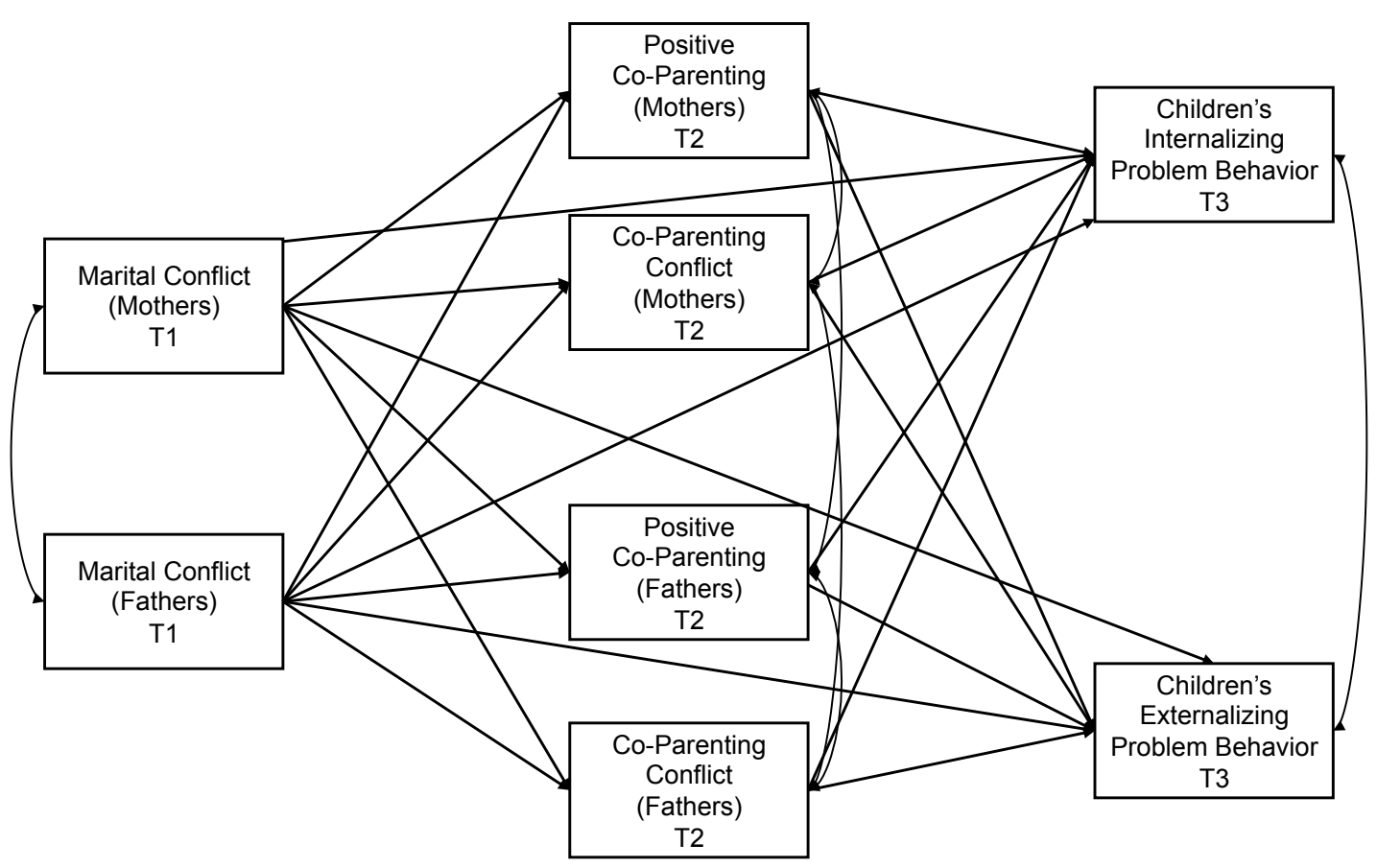

Figure 1. Research model.

로 평정하도록 구성된 3점 리커트 척도이다. 내재적 문제행동 을 측정하는 문항의 예로는 "아무도 자기를 사랑하지 않는다 고 생각하거나 불평한다.”, “신경이 날카롭고 곤두서 있거나 긴장되어있다.”, “뚜렷한 의학적 원인 없이 나타나는 신체적 문제(예: 두통)가 있다.” 등이 있다. 외현적 문제행동을 측정하 는 문항의 예로는 "남에게 잔인한 짓을 하거나 괴롭히고 못살 게 군다.”, "가족이나 다른 아이의 물건을 부순다.”, "거짓말을 하거나 남들을 속인다." 등이 있다. 내재적 문제행동의 점수가 높을수록 외적으로 문제가 표출되기보다는 위축되거나 과잉 통제된 행동과 같은 내적인 문제행동이 높음을 의미한다. 반 면에 외현적 문제행동은 점수가 높을수록 통제가 어렵고, 남 에게 해를 입히는 등 외적으로 분명하게 표출되는 문제행동이 높음을 의미한다. 본 연구에서 산출한 내재적 문제행동 32 개 문항(Time 3)에 대한 내적합치도 계수 Cronbach's $\alpha$ 는 .83이었 고, 외현적 문제행동 35개 문항(Time 3)에 대한 내적합치도 계 수 Cronbach's $\alpha$ 는 .87이었다.

\section{통제변인}

본 연구에서는 Time 1 의 부모의 교육수준과 아동의 성별을 통 제변인으로 사용하였다. 선행연구에 따라 부모의 교육수준과 가족소득 및 아동의 성별이 통제변인으로 고려되었으나 가족 소득은 본 연구의 주요 변인들과 유의한 관계가 없는 것으로
나타나 부모의 교육수준과 아동의 성별만이 통제되었다(Han, Rudy, \& Proulx, 2017). 아동의 보호자(어머니가 99\%)가 부모 의 교육수준과 성별을 응답하였고, 부모의 교육수준은 무학(1 점)에서 대학원 졸업(7점)의 범위로 평정하는 7점 리커트 척도 를 사용하여 응답하였다.

\section{자료분석}

먼저, 연구변인들에 대한 사전분석을 위하여 SPSS WIN 21.0 (IBM Co., Armonk, NY)을 사용하여 연구변인들의 평균, 표준 편차, 상관관계를 살펴보았다. 다음으로 연구변인들 간의 종 단적 관계를 살펴보기 위하여 STATA 14.2 (StataCorp, 2015)를 통해 경로분석(path analysis)을 실시하였다. 경로분석에 있어 부모의 교육수준과 아동의 성별은 통제하여 분석하였다. 연구 모형은 Figure 1에 제시하였다. 독립변인인 부부갈등과 통제변 인들 간의 관계가 있다고 설정하였고, 종속변인인 아동의 내 재적 문제행동과 외현적 문제행동의 잔차(residual) 간의 관계 가 있다고 설정하였다. 또한 Figure 1에 제시한 바와 같이 매개 변수들의 잔차(residual) 간의 관계가 있다고 설정하였다. 패널 자료의 결측치 처리는 완전정보 최대우도법(full information maximum likelihood)을 사용하였다. 마지막으로, 매개효과의 검증을 위하여 부트스트래핑을 사용하였다(Preacher \& Hayes, 2008). 


\section{Results}

\section{연구변인들에 대한 사전 분석}

본 연구에서는 어머니와 아버지가 지각하는 부부갈등, 어머니 와 아버지의 긍정적 공동양육행동과 공동양육 갈등, 아동의 내재적·외현적 문제행동을 주요 연구변인들로 설정하였다. Table 2에는 사전분석을 통해 살펴 본 연구변인들에 대한 평 균, 표준편차, 상관관계를 제시하였다. 경로분석을 실시하기 앞서 연구변인들 간의 유의한 상관관계가 있는지 살펴보기 위 하여 상관분석을 실시하였다. 연구변인들 간의 유의한 상관이 나타났으며, 결과는 Table 2에 제시한 바와 같다. 또한 선행연 구에 따라 부모의 사회경제적 수준과 아동의 성별이 통제변인 으로 고려되었고, 본 연구의 주요 연구변인들과 관계가 있는 지 살펴보았다. 그 결과, 부모의 교육수준은 어머니의 긍정적 인 공동양육행동 $(\beta=.08, S E=.02, p<.01)$, 아버지의 긍정적인 공동양육행동 $(\beta=.10, S E=.03, p<.001)$, 아동의 외현적 문제 행동 $(\beta=-.07, S E=.03, p<.01)$ 과 관계가 있었고, 아동의 성별 은 외현적 문제행동 $(\beta=-.11, S E=.02, p<.001)$ 과 관계가 있는 것으로 나타났다. 가족소득은 연구변인들과 관계가 없는 것으 로 나타나 통제하지 않았고(Han et al., 2017), 최종분석에는 부 모의 교육수준과 아동의 성별이 통제변인으로 사용되었다.

\section{연구변인들에 대한 경로분석}

본 연구에서는 연구변인들 간의 직·간접 및 종단적 관계가 있 는지 살펴보았다. 연구모델에 대한 분석결과는 Figure 2에 제 시한 바와 같다. 모델적합도는 $\chi^{2}(2)=27.16, p<.001, \mathrm{RMSEA}=$ $.07, \mathrm{CFI}=.99$ 로, 충분한 모델적합도를 갖추었다(SchermellehEngel, Moosbrugger, \& Müller, 2003). 먼저, 연구변인들 간에 직 접효과가 나타나는지 알아보았다. Time 1에서 측정한 어머니 와 아버지가 지각하는 부부갈등이 Time 3에 측정한 아동의 내 재적·외현적 문제행동에 미치는 직접적인 영향을 살펴본 결 과, 어머니가 지각하는 부부갈등이 이후 아동의 외현적 문제 행동과 직접적인 관계가 있었다 $(\beta=.08, S E=.03, p<.05)$.

또한, Time 1 에서 측정한 어머니와 아버지가 지각하는 부 부갈등이 Time 2에 측정한 어머니와 아버지의 긍정적인 공 동양육행동 및 공동양육 갈등과 직접적인 관계가 있는지 살 펴보았다. 그 결과, 어머니가 지각하는 부부갈등은 이후 자신 의 긍정적인 공동양육행동 $(\beta=-.31, S E=.03, p<.001)$ 과 공동 양육 갈등 $(\beta=.31, S E=.03, p<.001)$ 과 직접적인 관계가 있었 고, 아버지의 이후 긍정적인 공동양육행동 $(\beta=-.17, S E=.03, p$ $<.001)$ 과 공동양육 갈등 $(\beta=.18, S E=.03, p<.001)$ 과도 직접 적인 관계가 나타났다. 아버지가 지각하는 부부갈등 역시 이 후 자신의 긍정적인 공동양육행동 $(\beta=-.21, S E=.03, p<.001)$ 과 공동양육 갈등 $(\beta=.34, S E=.03, p<.001)$ 과 직접적인 관계

Table 2

Descriptive Statistics and Correlations for the Variables

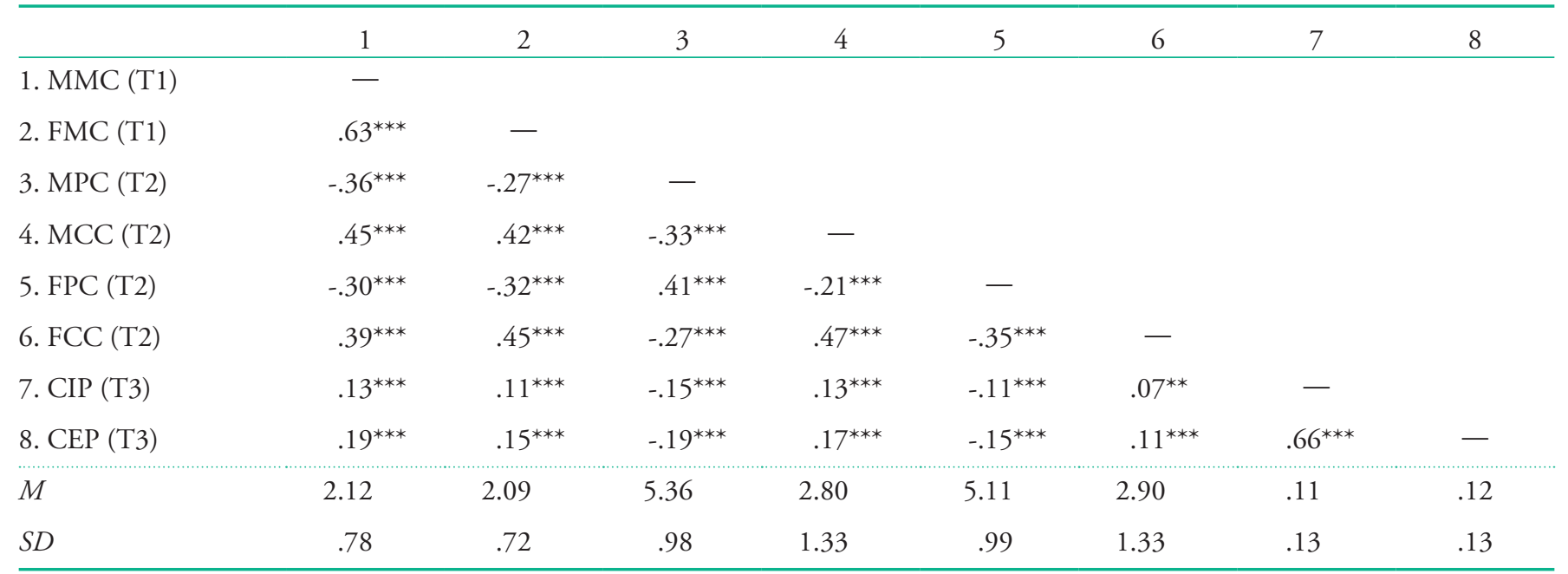

Note MMC = mothers' perceptions of marital conflict; FMC = fathers' perceptions of marital conflict; $\mathrm{MPC}=$ mothers' positive coparenting; $\mathrm{MCC}=$ mothers' coparenting conflict; FPC = fathers' positive coparenting; $\mathrm{FCC}=$ fathers' coparenting conflict; CIP = children's internalizing problem behavior; CEP = children's externalizing problem behavior.

${ }^{* *} p<.01 .{ }^{* * *} p<.001$. 


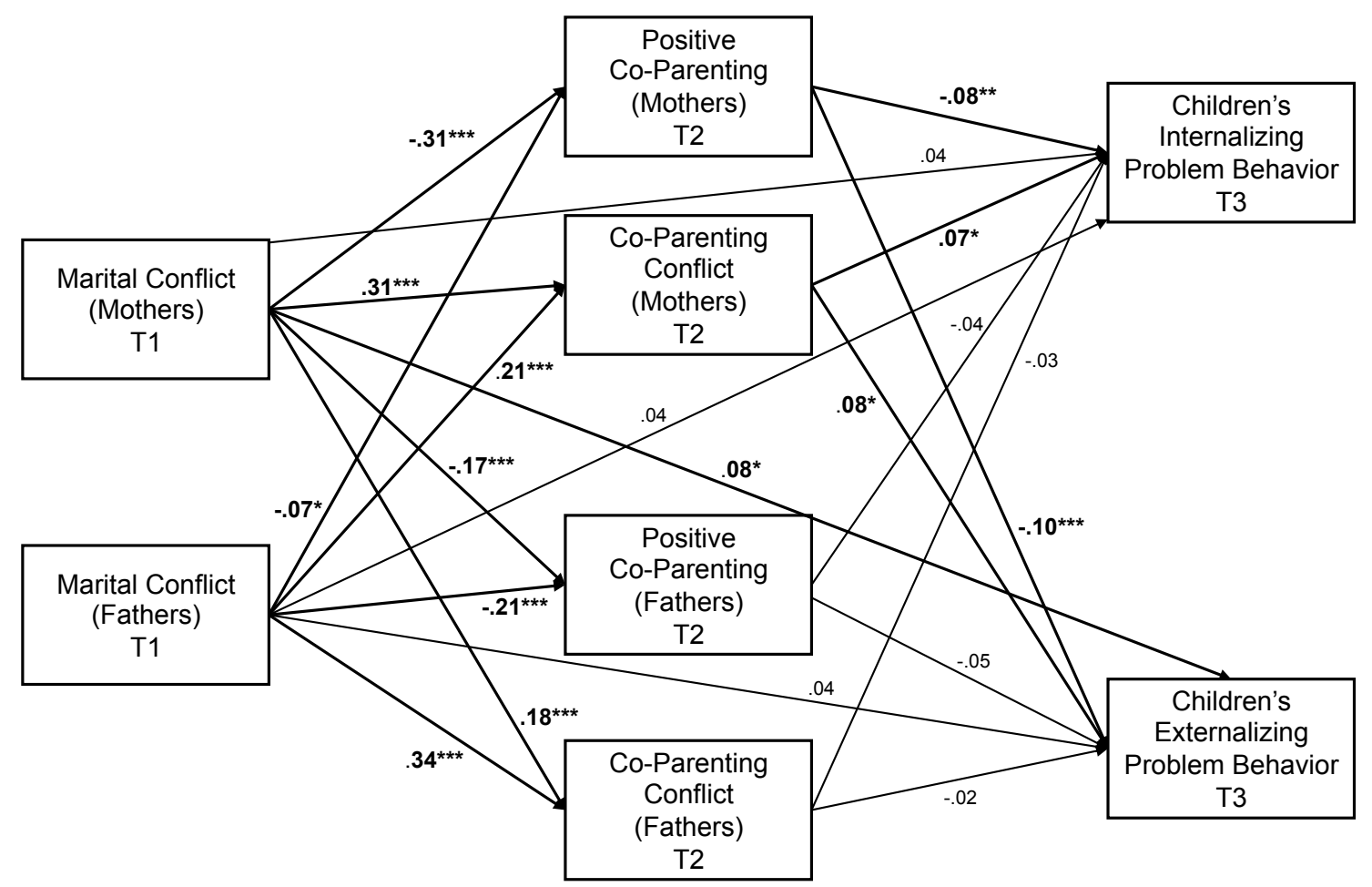

Figure 2. Longitudinal relations among marital conflict, co-parenting, and children's internalizing and externalizing problem behaviors.

${ }^{*} p<.05 .{ }^{* *} p<.01 .{ }^{* * *} p<.001$.

가 있었고, 어머니의 이후 긍정적인 공동양육행동 $(\beta=-.07, S E$ $=.03, p<.05)$ 과 공동양육 갈등 $(\beta=.21, S E=.03, p<.001)$ 과도 직접적인 관계가 있는 것으로 나타났다.

다음으로는 Time 2에서 측정한 어머니와 아버지의 긍정적 인 공동양육행동 및 공동양육 갈등이 Time 3 에 측정한 아동의 내재적·외현적 문제행동과 직접적인 관계가 있는지 알아보 았다. 그 결과, 어머니의 긍정적인 공동양육행동은 아동의 내 재적 문제행동 $(\beta=-.08, S E=.03, p<.01)$ 과 외현적 문제행동 $(\beta$ $=-.10, S E=.03, p<.001)$ 과 직접적인 관계가 있는 것으로 나타 났다. 어머니의 공동양육 갈등 역시 아동의 내재적 문제행동 $(\beta=.07, S E=.03, p<.05)$ 과 외현적 문제행동 $(\beta=.08, S E=.03$, $p$ <.05)과 직접적인 관계를 보였다. 그러나 아버지의 긍정적 인 공동양육행동과 공동양육 갈등은 아동의 내재적-외현적 문제행동과 직접적인 관계가 나타나지 않았다.

위의 결과들을 종합해보면, 어머니와 아버지가 지각하는 부부갈등은 각각 자신과 배우자의 이후 긍정적-갈등적 공동 양육행동에 직접적인 영향을 미쳤다. 이어서 어머니의 긍정적 공동양육행동은 일년 후 아동의 내재적.외현적 문제행동을 예측하였고, 어머니의 갈등적 공동양육행동은 일년 후 아동의
내재적·외현적 문제행동을 예측하는 것으로 나타났다. 이러 한 연구결과는 어머니의 긍정적 공동양육행동과 공동양육 갈 등이 부부갈등과 아동의 내재적·외현적 문제행동 간의 종단 적 관계에서 매우 중요한 역할은 한다는 것을 의미한다.

이를 토대로 Time 1에서 측정한 어머니와 아버지가 지각하 는 부부갈등과 Time 3 에 측정한 아동의 내재적. 외현적 문제 행동과의 관계에서 Time 2에 측정한 부모의 공동양육행동이 매개효과를 보이는지 검증하였다. 그 결과, 어머니가 지각하 는 부부갈등은 어머니의 긍정적인 공동양육행동(CIs $=.0052$ $\sim .0056, p<.05$ )과 공동양육 갈등(CIs = .0004 .0069, $p<.05)$ 을 통하여 아동의 이후 내재적 문제행동을 간접적으로 예측하 였다. 또한 어머니가 지각하는 부부갈등은 어머니의 긍정적인 공동양육행동(CIs $=.0042 ~ .0072, p<.05)$ 과 공동양육 갈등 $(\mathrm{CIs}=.0033 \sim .0054, p<.05)$ 을 통하여 아동의 이후 외현적 문 제행동을 간접적으로 예측하였다. 아버지가 지각하는 부부갈 등 역시 어머니의 긍정적인 공동양육행동(CIs = .0005 .0015, $p<.05)$ 과 공동양육 갈등 $(\mathrm{CIs}=.0002 \sim .0033, p<.05)$ 을 통하 여 아동의 이후 내재적 문제행동을 간접적으로 예측하였다. 어머니의 긍정적인 공동양육행동(CIs $=.0006 ~ .0012, p<.05)$ 
과 공동양육 갈등(CIs $=.0020 ~ .0027, p<.05)$ 은 아버지가 지 각하는 부부갈등과 아동의 이후 외현적 문제행동 간의 관계에 서도 매개하였다. 종합하면, 어머니의 긍정적 공동양육행동과 공동양육 갈등은 어머니와 아버지가 지각하는 부부갈등과 이 후 아동의 내재적·외현적 문제행동 간의 관계를 설명하는 중 요한 메커니즘임을 알 수 있다.

\section{Discussion}

본 연구에서는 어머니와 아버지가 지각한 부부갈등, 어머니와 아버지의 긍정적 공동양육행동과 공동양육 갈등, 아동의 내재 적·외현적 문제행동 간의 직접적·종단적 관계가 있는지 알아 보았다. 또한 어머니와 아버지가 지각한 부부갈등이 어머니와 아버지의 긍정적 공동양육행동과 공동양육 갈등을 통하여 아 동의 내재적-외현적 문제행동을 예측하는지 살펴보았다. 다 음에서는 본 연구결과들에 대해 논의하고 후속연구를 위한 제 언을 제시하였다.

첫째, 어머니가 지각하는 부부갈등은 삼년 후 아동의 외현 적 문제행동과 직접적인 관계가 있었다. 이는 부부갈등과 아 동의 외현적 문제행동 간의 유의한 관계를 밝힌 선행연구들 의 결과와 일치한다(Buehler et al., 1997; Kaczynski et al., 2006; Katz \& Gottman, 1993; Xuan et al., 2018). Bandura (1977)가 제 시한 사회학습이론(social leaning theory)에서는 아동이 타인의 행동을 관찰하고 모방함으로써 새로운 행동양식을 획득한다 고 설명하였다. 특히 자녀와 정서적인 관계를 맺고 있는 부모 는 자녀에게 있어 매우 영향력이 있는 모델로서 자녀의 행동 학습에 중요한 영향을 미칠 수 있다(Grych \& Fincham, 1990). 부모의 공격적이고 적대적인 부모 간 상호작용을 목격한 자녀 들의 경우, 갈등을 해결하는 데 있어 공격적인 방법이 타인과 의 상호작용에서 수용 가능한 또는 적절한 방식이라고 배우 고, 이를 모방할 가능성이 높다(Grych \& Fincham, 1990). 따라 서 본 연구에서 측정한 공격적·적대적 유형의 부부갈등에 자 주 노출된 아동일수록 이러한 부모의 행동양식을 학습하고 타 인에게 해를 가하거나 위협을 가하는 등의 외현적 문제행동을 보였을 것으로 추측할 수 있다. 그러나 대부분의 선행연구들 의 결과와 다르게 부부갈등은 아동의 내재적 문제행동과는 직 접적 관계가 나타나지 않았다. 이는 Brock과 Kochanska (2016) 의 연구에서 부부갈등이 이후 아동의 내재적 문제행동과 직접 적 관계는 나타나지 않았지만 정서적 안정성을 통해 간접적으 로 아동의 내재적 문제행동에 영향을 주었던 결과에서처럼,
본 연구에서는 측정되지 않은 다른 잠재경로가 존재할 가능성 이 있다.

둘째, 어머니와 아버지가 지각하는 부부갈등은 2년 후 자기 자신과 배우자의 긍정적인 공동양육행동 및 공동양육 갈등과 직접적인 관계가 있는 것으로 나타났다. 이는 부부갈등과 부 모의 공동양육행동 간의 유의한 관계를 밝힌 선행연구들의 결 과와 일치한다(Jang \& Choi, 2015; Katz \& Low, 2004; Margolin et al., 2001). 그러나 대부분의 선행연구들에서는 세부적으로 어머니와 아버지가 지각하는 부부갈등과 어머니와 아버지 의 공동양육행동을 살펴보지 않아(Jang \& Choi, 2015; Katz \& Low, 2004), 이에 대한 이해가 부족했다. 어머니와 아버지가 지각하는 부부 간 관계와 부모의 공동양육행동 간의 세부적 인 관계를 살펴본 소수의 연구들에서는 본 연구결과와 동일 하게 어머니와 아버지가 지각하는 부모 간 관계가 각각 자신 과 상대 배우자의 공동양육행동을 단기적-종단적으로 예측 하는 것으로 나타났다(Le, McDaniel, Leavitt, \& Feinberg, 2016; Margolin et al., 2001). 가족체계이론(family systems theory)에 따 르면, 가족체계들은 서로 유기적으로 연결되어있어 각 하위체 계들이 서로 영향을 주고받는다(Minuchin, 1985). 따라서 가 족의 하위체계 중 하나인 부모 간 관계는 다른 하위체계인 부 모의 공동양육관계에 부정적 또는 긍정적인 영향을 미칠 수 있다(Cox \& Paley, 1997). 본 연구결과는 가족체계를 연구함에 있어 어머니와 아버지를 포함시켜 분석함으로써 가족 상호작 용의 메커니즘에 대하여 보다 폭넓은 이해를 가능케 하였고, 가족체계들의 유기성을 강조한 결과임을 시사한다.

셋째, 어머니가 긍정적인 공동양육행동을 보일수록 아동 은 내재적-외현적 문제행동을 더 적게 보였고, 공동양육 갈등 을 보일수록 아동은 내재적·외현적 문제행동을 더 많이 보이 는 것으로 나타났다. 다수의 선행연구들에서도 긍정적인 공동 양육은 아동의 내재적·외현적 문제행동을 포함한 다양한 심 리사회적 부적응과 부적인 관계가 있는 반면에, 갈등과 비난 과 같은 부정적인 형태의 공동양육행동은 내재적·외현적 문 제행동과 정적인 관계가 있는 것으로 나타났다(Katz \& Low, 2004; Murphy et al., 2016; Murphy et al., 2017; Schoppe et al., 2001; Teubert \& Pinquart, 2010). 사회학습이론(Bandura, 1977) 에 근거하여, 공동양육 상황에서 어머니 또는 아버지가 상 대 배우자에 대해 비난 및 무시하고, 갈등을 일으키는 등 역 기능적 상호작용의 모습을 자주 표출할 경우, 이를 목격하는 자녀들은 부모의 공동양육행동을 학습하여 타인에게 적용 할 가능성이 높다. 또한 공동양육관계는 부모와 자녀의 관계 및 양육행동에 영향을 미침으로써 자녀의 내재적·외현적 문 
제행동을 예측할 가능성이 있다. 다수의 연구들에서 부모의 공동양육은 다양한 양육행동에 영향을 주는 것으로 나타났 다(Feinberg, Kan, \& Goslin, 2009; Margolin et al., 2001; Pedro, Ribeiro, \& Shelton, 2012). 예를 들어, Pedro 등(2012)의 연구에 서 어머니와 아버지의 긍정적인 공동양육행동은 배우자의 정 서적 지지와 통제적 양육과 정적인 관계가 있었고, 어머니와 아버지의 공동양육 갈등도 배우자의 정서적 지지와 거부적 양 육행동을 직접적으로 예측하는 것으로 나타났다.

어머니와 다르게 아버지의 긍정적 공동양육과 공동양육 갈등은 아동의 내재적-외현적 문제행동과 직접적 관계가 없 는 것으로 나타났다. 대부분의 선행연구들(Katz \& Low, 2004;

Murphy et al., 2016; Murphy et al., 2017; Schoppe et al., 2001)은 관찰자의 평정에 의해 부모의 통합적인 공동양육행동을 측정 하였기 때문에 어머니와 아버지 각각의 공동양육행동이 아동 의 적응에 미치는 영향을 살펴보지 않아 본 연구결과와는 비 교하기가 어렵다. 그러나 연구자들은 공동양육관계에서 어머 니와 아버지의 기능이 다를 수 있음으로 강조하며, 어머니와 아버지 각각의 공동양육행동을 살펴볼 필요가 있음을 주장하 였다(Margolin et al., 2001). 특히 어머니는 아버지에 비해 협동 적·긍정적인 공동양육행동을 더 많이 보이는 경향이 있기 때 문에(Margolin et al., 2001), 어머니의 공동양육행동이 아버지 의 공동양육행동보다 아동의 발달에 더 유의한 영향을 미칠 가능성이 있다. 대체적으로 어머니는 가정의 주 양육자로서 의 역할과 책임감이 크고, 자녀와 보내는 시간이 아버지에 비 해 더 많아 자녀의 발달에 미치는 영향력이 더 클 수 있다. 또 한 본 연구의 상관분석에서는 아버지의 긍정적 공동양육행동 과 공동양육 갈등이 아동의 내재적·외현적 문제행동과 관계 가 있는 것으로 나타났으나 경로분석에서는 이러한 유의한 관 계가 어머니의 공동양육행동 및 다른 연구변인들을 함께 설 명함으로써 약화되었을 가능성이 있다(Han, 2019). 아울러 본 연구에서는 아동의 문제행동을 어머니가 평정하도록 하였기 때문에 어머니의 공동양육행동과 아동의 문제행동 간의 관계 가 더욱 유의한 관계가 있는 것으로 나타났을 가능성도 있다. 마지막으로 아버지의 공동양육행동이 아동의 내재적-외현적 문제행동과 직접적 관계는 없었으나 다른 메커니즘을 통하여 간접적인 영향을 미칠 수 있다. 예컨대, 선행연구에서 부모의 공동양육행동은 양육스트레스(Margolin et al., 2001) 및 아버 지의 양육참여(Cabrera, Shannon, \& La Taillade, 2009)를 예측 한다고 밝혔다. 따라서 아버지의 공동양육행동이 아버지의 양 육스트레스 또는 양육참여를 통해 자녀의 심리사회적 적응에 간접적인 영향을 주었을 가능성을 고려해 볼 수 있다.
넷째, 어머니와 아버지가 지각하는 부부갈등이 이후 아동 의 내재적·외현적 문제행동을 예측하는 데 있어 어머니의 긍 정적 공동양육행동 및 공동양육 갈등이 매개하는 것으로 나 타났다. 이러한 결과는 부부 간 관계와 아동의 내재적·외현적 문제행동 간의 관계에서 공동양육행동의 매개 효과를 밝힌 선 행연구들과 일치한다(Baril, Crouter, \& McHale, 2007; Jang \& Choi, 2015; Katz \& Low, 2004; Stroud et al., 2015). 예를 들어, Katz와 Low (2004)의 연구에서는 부부관계에서 신체적인 공격 성을 자주 드러내는 등 부부 간의 갈등이 빈번한 부모의 자녀 일수록 적대적인 형태의 부모공동양육 행동에 더 많이 노출됨 으로써 불안과 우울을 더 많이 경험하는 것으로 나타났다. 또 다른 연구에서도 부부 간의 관계가 좋지 못할수록 온정적인 부모공동양육 행동이 감소하였고, 낮은 수준의 부모공동양육 행동은 다시 아동의 내재적-외현적 문제행동을 예측하는 등 발달을 저해하는 것으로 나타났다(Stroud et al., 2015). 국내연 구에서도 부부갈등이 지지적인 부모공동양육 행동을 통하여 학령기 아동의 공격성에 간접적인 영향을 미치는 것으로 나타 났다(Jang \& Choi, 2015). 본 연구결과는 이처럼 관련 선행연 구들과 일치하며, 전이 모델(spillover model)을 지지하는 결과 라고 할 수 있다. 전이 모델에 따르면, 부부 간의 관계가 이들 의 공동양육행동과 양육행동에 영향을 줌으로써 아동의 적응 을 예측한다고 설명하고 있다(Stroud et al., 2015). 가족체계이 론에서도 설명하고 있듯이, 가족체계들은 상호영향을 주고받 는 유기적 존재이기 때문에(Minuchin, 1985), 부정적인 부모 간의 관계는 이들의 공동양육 관계에 쉽게 전이가 되는 특성 이 있다. 이러한 부정적 영향을 받은 공동양육관계는 다시 아 동의 발달에 부정적인 영향을 미치게 되는 것이다. 본 연구결 과는 특히 어머니의 공동양육행동이 부부갈등과 아동의 적응 간의 관계를 설명하는 데 있어 중요한 요인임을 밝혔다. 이는 아동의 내재적-외현적 문제행동을 해결하기 위해서는 어머 니가 아버지 및 자녀와 함께 있을 때 아버지에 대해 긍정적인 말을 하는 등 자녀로 하여금 아버지와 좋은 관계를 맺을 수 있 도록 돕고, 긍정적인 공동양육행동을 보일 필요가 있음을 시 사한다. 또한 자녀가 지켜보는 앞에서 배우자에게 대화할 때 무시하거나 빈정대는 말투를 삼가는 등 공동양육 상황에서 배 우자와의 갈등을 최소화하려는 노력을 하는 것이 중요함을 시 사한다.

다음으로는 본 연구의 제한점에 대하여 논의하고, 후속연 구를 위한 제언을 제시하였다. 첫째, 본 연구에서는 부모의 지 필식 질문지를 통하여 자신이 지각하는 부부갈등과 자신의 공 동양육행동을 보고하였고, 어머니의 지필식 질문지를 사용하 
여 아동의 내재적·외현적 문제행동을 측정하였다. 후속연구 에서는 아동의 문제행동을 평가하기 위하여 아버지나 교사와 같이 다양한 보고자를 포함시킴으로써 보고자에 따라 어떻게 결과가 달라지는지 파악할 필요가 있다. 또한 보다 객관적이 고 풍성한 정보를 얻기 위하여 지필식 질문지만을 사용하는 것이 아니라 여러가지 상황에서 연구자의 관찰을 통한 평정을 포함시키는 등 다양한 연구방법들을 시도해 볼 필요가 있다. 둘째, 본 연구는 부부갈등이 부모공동양육을 통해 아동의 내 재적·외현적 문제행동에 미치는 일방적 방향만을 살펴보았 다. 그러나 가족체계이론에서 설명하였듯이 부부갈등과 부모 의 공동양육행동은 서로 영향을 주고받을 수 있고, 아동의 문 제행동 역시 부모에게 영향을 미칠 수 있다. 따라서 후속연구 에서는 양방향 연구를 통하여 가족상호작용의 역동성에 대해 보다 풍성한 정보를 제공해 줄 수 있을 것이다. 셋째, 본 연구 에서는 부정적 측면의 부부갈등과 아동의 문제행동에 초점을 맞추어 긍정적 측면의 부부갈등이나 부부관계의 질이 어떻게 부모의 공동양육과 아동의 친사회성과 같은 긍정적 발달에 영 향을 미치는지에 대해 설명하지 않았다. 후속연구에서는 긍정 적·부정적 측면의 부모 관계가 어떻게 긍정적·부정적 측면의 공동양육행동 및 아동 발달에 영향을 미치는지 살펴봄으로써, 연구변인들 간의 관계에 대한 이해를 높일 필요가 있다. 넷째, 본 연구는 패널 $5,7,8$ 차년도의 자료를 분석한 것으로 Time 1 과 Time 2, Time 2 와 Time 3의 간격이 각각 2년과 1년으로 차 이가 있다. 가족체계이론에 기반하여 부부갈등, 부모공동양 육, 아동의 내재적·외현적 문제행동 간의 종단 관계를 살펴보 고자 하였으나 본 연구에서 관심있는 부부갈등 변인은 패널 6 차년도에는 포함되지 않아 5 차년도 자료가 사용되었다. 이는 패널데이터를 활용하는 연구의 한계점으로 추후 연구자가 자 료를 동일한 간격으로 직접 수집하는 후속연구를 통하여 연 구변인들 간의 관계를 살펴볼 필요가 있겠다. 다섯째, 본 연구 는 부부갈등과 부모공동양육에 따른 아동의 전반적인 심리사 회적 적응을 살펴보기 위하여 내재적 문제행동과 외현적 문제 행동으로 나누어 살펴보았으나 위축이나 공격성과 같은 문제 행동의 하위요인별로 어떻게 다른지에 대한 정보를 제공하지 않고 있다. 따라서 추후 어머니와 아버지 간의 갈등과 공동양 육행동이 문제행동의 하위요인별로 어떻게 서로 다른 영향을 미치는지에 대한 연구를 통해 보다 구체적인 정보를 제공해줄 수 있을 것이다.

마지막으로, 본 연구는 다음과 같은 장점 및 시사점을 가졌 다. 첫째, 본 연구는 전국 지역의 아동들과 부모들을 대상으로 자료를 수집한 한국아동패널 자료를 사용함으로써 다른 선행
연구들에 비해 한국가정에 대한 표본의 대표성을 확보했다고 볼 수 있다. 이는 개인연구자가 실행하기 어려운 부분으로, 개 인이 수집하게 되었을 경우 많이 사용하게 되는 편의표집법과 같은 방법을 사용하지 않고, 층화다단계 표본추출법을 통하여 오차를 최소화하였다. 둘째, 본 연구는 다수의 선행연구들에 서 횡단적 자료를 사용한 것과 다르게 3 개년도 종단적 자료를 통하여 부부갈등이 얼마나 지속적으로 공동양육행동과 아동 의 문제행동을 예측하는지 살펴보았다. 이러한 결과는 부정적 인 형태의 부부갈등이 빈번한 가정의 자녀의 내재적·외현적 문제행동을 예방하기 위한 조기중재 및 대책이 필요함을 강조 하는 결과임을 시사한다. 셋째, 본 연구는 어머니와 아버지를 모두 포함시켜 이들이 지각하는 부부갈등과 어머니와 아버지 각각의 공동양육행동을 세부적으로 살펴봄으로써 보다 구체 적인 중재방안을 제공할 수 있었다. 특히 아버지보다는 어머 니의 긍정적인 공동양육행동을 강화하고 공동양육 갈등을 줄 임으로써 자녀의 내재적·외현적 문제행동을 예방할 수 있음 을 시사한다. 또한 이를 위해서는 비난이나 무시와 같은 부정 적인 형태의 부부갈등이 감소될 수 있도록 중재하는 것이 무 엇보다 중요함을 시사한다.

\section{Notes}

This article was presented at the 2019 Biennial Meeting of the Society for Research in Child Development, Baltimore, MD.

\section{Conflict of Interest}

No potential conflict of interest relevant to this article was reported.

\section{References}

\section{In English}

Bandura, A. (1977). Social learning theory. Englewood Cliffs, NJ: Prentice-Hall.

Baril, M. E., Crouter, A. C., \& McHale, S. M. (2007). Processes linking adolescent well-being, marital love, and coparenting. Journal of Family Psychology, 21(4), 645-654. doi:10.1037/0893-3200.21.4.645 
Bøe, T., Sivertsen, B., Heiervang, E., Goodman, R., Lundervold, A. J., \& Hysing, M. (2014). Socioeconomic status and child mental health: The role of parental emotional well-being and parenting practices. Journal of Abnormal Child Psychology, 42(5), 705-715. doi:10.1007/s10802-013-9818-9

Brock, R. L., \& Kochanska, G. (2016). Interparental conflict, children's security with parents, and long-term risk of internalizing problems: A longitudinal study from ages 2 to 10. Development and Psychopathology, 28(1), 45-54. doi:10.1017/S0954579415000279

Buehler, C., Anthony, C., Krishnakumar, A., Stone, G., Gerard, J., \& Pemberton, S. (1997). Interparental conflict and youth problem behaviors: A meta-analysis. Journal of Child and Family Studies, 6(2), 233-247. doi:10.1023/A:1025006909538

Buehler, C., \& Gerard, J. M. (2004). Marital conflict, ineffective parenting, and children's and adolescents' maladjustment. Journal of Marriage and Family, 64(1), 78-92. doi:10.1111/ j.1741-3737.2002.00078.x

Cabrera, N. J., Shannon, J. D., \& La Taillade, J. J. (2009). Predictors of coparenting in Mexican American families and links to parenting and child social emotional development. Infant Mental Health Journal, 30(5), 523-548. doi:10.1002/ imhj.20227

Camisasca, E., Miragoli, S., \& Blasio, P. D. (2016). Families with distinct levels of marital conflict and child adjustment: Which role for maternal and paternal stress? Journal of Child and Family Studies, 25(3), 733-745. doi:10.1007/ s10826-015-0261-0

Camisasca, E., Miragoli, S., Blasio, P. D., \& Feinberg, M. (2019). Co-parenting mediates the influence of marital satisfaction on child adjustment: The conditional indirect effect by parental empathy. Journal of Child and Family Studies, 28(2), 519-530. doi:10.1007/s10826-018-1271-5

Christopher, C., Umemura, T., Mann, T., Jacobvitz, D., \& Hazen, N. (2015). Marital quality over the transition to parenthood as a predictor of coparenting. Journal of Child and Family Studies, 24(12), 3636-3651. doi:10.1007/ s10826-015-0172-0

Cox, M. J., \& Paley, B. (1997). Families as systems. Annual Review of Psychology, 48, 243-267. doi:10.1146/annurev. psych.48.1.243

Cummings, E. M., \& Davies, P. T. (2010). Marital conflict and children: An emotional security perspective. New York: The Guilford Press.

Feinberg, M. E., Kan, M. L., \& Goslin, M. C. (2009). Enhancing coparenting, parenting, and child self-regulation: Effects of family foundations 1 year after birth. Prevention Science, 10(3), 276-285. doi:10.1007/s11121-009-0130-4

Grych, J. H., \& Fincham, F. D. (1990). Marital conflict and children's adjustment: A cognitive-contextual framework.
Psychological Bulletin, 108(2), 267-290. doi:10.1037/00332909.108.2.267

Han, Y., Rudy, D., \& Proulx, C. M. (2017). Longitudinal relationships among marital conflict, maternal and paternal warmth and control, and preschoolers' socioemotional outcomes in South Korea. Journal of Cross-Cultural Psychology, 48(10), 15221536. doi: $10.1177 / 0022022117732300$

Hardesty, J. L., Crossman, K. A., Khaw, L., \& Raffaelli, M. (2016). Marital violence and coparenting quality after separation. Journal of Family Psychology, 30(3), 320-330. doi:10.1037/ fam0000132

Kaczynski, K. J., Lindahl, K. M., Malik, N. M., \& Laurenceau, J.-P. (2006). Marital conflict, maternal and paternal parenting, and child adjustment: A test of mediation and moderation. Journal of Family Psychology, 20(2), 199-208. doi:10.1037/0893-3200.20.2.199

Katz, L. F., \& Gottman, J. M. (1993). Patterns of marital conflict predict children's internalizing and externalizing behaviors. Developmental Psychology, 29(6), 940-950. doi:10.1037/0012-1649.29.6.940

Katz, L. F., \& Low, S. M. (2004). Marital violence, co-parenting, and family-level processes in relation to children's adjustment. Journal of Family Psychology, 18(2), 372-382. doi:10.1037/0893-3200.18.2.372

Le, Y., McDaniel, B. T., Leavitt, C. E., \& Feinberg, M. E. (2016). Longitudinal associations between relationship quality and coparenting across the transition to parenthood: A dyadic perspective. Journal of Family Psychology, 30(8), 918-926. doi:10.1037/fam0000217

Leadbeater, B. J., Kuperminc, G. P., Blatt, S. J., \& Hertzog, C. (1999). A multivariate model of gender differences in adolescents' internalizing and externalizing problems. Developmental Psychology, 35(5), 1268-1282. doi:10.1037/00121649.35.5.1268

Lindsey, E. W., Caldera, Y. M., \& Tankersley, L. (2009). Marital conflict and the quality of young children's peer play behavior: The mediating and moderating role of parentchild emotional reciprocity and attachment security. Journal of Family Psychology, 23(2), 130-145. doi:10.1037/ a0014972

Margolin, G., Gordis, E. B., \& John, R. S. (2001). Coparenting: A link between marital conflict and parenting in twoparent families. Journal of Family Psychology, 15(1), 3-21. doi:10.1037/0893-3200.15.1.3

Markman, H., Stanley, S. L., \& Blumberg, S. (1994). Fighting for your marriage: Poitive steps for preventing divorce and preserving a lasting love. San Francisco, CA: Jossey-Bass

Markman, H., Stanley, S., \& Blumberg, S. (2001). Fighting for your marriage: Positive steps for preventing divorce and preserving a lasting love, New \& Revised. San Francisco, CA: Jossey-Bass. 
McHale, J. P. (1997). Overt and covert coparenting processes in the family. Family Process, 36(2), 183-201. doi:10.1111/ j.1545-5300.1997.00183.x

Minuchin, P. (1985). Families and individual development: Provocations from the field of family therapy. Child Development, 56(2), 289-302. doi:10.2307/1129720

Moilanen, K. L., Shaw, D. S., \& Maxwell, K. L. (2010). Developmental cascades: Externalizing, internalizing, and academic competence from middle childhood to early adolescence. Development and Psychopathology, 22(3), 635653. doi:10.1017/S0954579410000337

Murphy, S. E., Boyd-Soisson, E., Jacobvitz, D. B., \& Hazen, N. L. (2017). Dyadic and triadic family interactions as simultaneous predictors of children's externalizing behaviors. Family Relations: Interdisciplinary Journal of Applied Family Studies, 66(2), 346-359. doi:10.1111/ fare. 12225

Murphy, S. E., Jacobvitz, D. B., \& Hazen, N. L. (2016). What's so bad about competitive coparenting? Family-level predictors of children's externalizing symptoms. Journal of Child and Family Studies, 25(5), 1684-1690. doi:10.1007/s10826015-0321-5

Odgers, C. L., Moffitt, T. E., Broadbent, J. M., Dickson, N., Hancox, R. J., Harrington, H., ... Caspi, A. (2008). Female and male antisocial trajectories: From childhood origins to adult outcomes. Development and Psychopathology, 20(2), 673-716. doi:10.1017/S0954579408000333

Parkes, A., Green, M., \& Mitchell, K. (2019). Coparenting and parenting pathways from the couple relationship to children's behavior problems. Journal of Family Psychology, 33(2), 215-225. doi:10.1037/fam0000492

Pedro, M. F., Ribeiro, T., \& Shelton, K. H. (2012). Marital satisfaction and partners' parenting practices: The mediating role of coparenting behavior. Journal of Family Psychology, 26(4), 509-522. doi:10.1037/a0029121

Preacher, K. J., \& Hayes, A. F. (2008). Asymptotic and resampling strategies for assessing and comparing indirect effects in multiple mediator models. Behavior Research Methods, 40(3), 879-891. doi:10.3758/BRM.40.3.879

Reising, M. M., Watson, K. H., Hardcastle, E. J., Merchant, M. J., Roberts, L., Forehand, R., \& Compas, B. E. (2013). Parental depression and economic disadvantage: The role of parenting in associations with internalizing and externalizing symptoms in children and adolescents. Journal of Child and Family Studies, 22(3), 335-343. doi:10.1007/ s10826-012-9582-4

Schermelleh-Engel, K., Moosbrugger, H., \& Müller, H. (2003). Evaluating the fit of structural equation models: Tests of significance and descriptive goodness-of-fit measures. Method of Psychological Research, 8(2), 23-74.
Schoppe, S. J., Mangelsdorf, S. C., \& Frosch, C. A. (2001). Coparenting, family process, and family structure: Implications for preschoolers' externalizing behavior problems. Journal of Family Psychology, 15(3), 526-545. doi:10.1037/0893-3200.15.3.526

Schoppe-Sullivan, S. J., Mangelsdorf, S. C., Frosch, C. A., \& McHale, J. L. (2004). Associations between coparenting and marital behavior from infancy to the preschool years. Journal of Family Psychology, 18(1), 194-207. doi:10.1037/0893-3200.18.1.194

Stroud, C. B., Durbin, C. E., Wilson, S., \& Mendelsohn, K. A. (2011). Spillover to triadic and dyadic systems in families with young children. Journal of Family Psychology, 25(6), 919-930. doi:10.1037/a0025443

Stroud, C. B., Meyers, K. M., Wilson, S., \& Durbin, C. E. (2015). Marital quality spillover and young children's adjustment: Evidence for dyadic and triadic parenting as mechanisms. Journal of Clinical Child \& Adolescent Psychology, 44(5), 800-813. doi:10.1080/15374416.2014.900720

Teubert, D., \& Pinquart, M. (2010). The association between coparenting and child adjustment: A meta-analysis. Parenting: Science and Practice, 10(4), 286-307. doi:10.108 0/15295192.2010.492040

Xuan, X., Chen, F., Yuan, C., Zhang, X., Luo, Y., Xue, Y., \& Wang, Y. (2018). The relationship between parental conflict and preschool children's behavior problems: A moderated mediation model of parenting stress and child emotionality. Children and Youth Services Review, 95, 209216. doi:10.1016/j.childyouth.2018.10.021

Zemp, M., Johnson, M. D., \& Bodenmann, G. (2018). Withinfamily processes: Interparental and coparenting conflict and child adjustment. Journal of Family Psychology, 32(3), 299309. doi:10.1037/fam0000368

\section{In Korean}

Han, Y. (2019). Longitudinal relations between parenting stress and young children's aggressive and cooperative behaviors: The mediating effect of co-parenting. Korean Journal of Child Studies, 40(2), 75-86. doi:10.5723/kjcs.2019.40.2.75

Jang, M., \& Choi, M.-K. (2015). Influence of marital conflict on children's aggression: The mediation effect of co-parenting. Family and Environment Research, 53(5), 567-580. doi:10. 6115/fer.2015.045

Oh, K., \& Kim, Y. (2009). CBCL 6-18 manual. Seoul: Hunocunsulting.

Shin, N., Ahn, J., Lee, J., Song, S., \& Kim, Y. (2008). Hangugadongpaeneol 2008 [한국아동패널 2008](Report No. 2008-08). Seoul: Korea Institute of Child Care and Education. 


\section{KJCS}

\section{ORCID}

Youngsook Han https://orcid.org/0000-0001-8974-3684

Received June 30, 2019

Revision received August 8, 2019

Accepted August 12, 2019 